\title{
Effect of environment on ovarian activity of wild hopping mice (Notomys alexis)
}

\author{
W. G. Breed \\ Department of Anatomy, University of Adelaide, Adelaide 5001, South Australia
}

It has been shown that laboratory-bred female hopping mice usually cease to have regular 7-9 day oestrous cycles when deprived of water and given only dry seeds as food (Breed, 1975). Body, ovarian and uterine weights tended to be lower, and it was therefore suggested that the availability of water, either free or in plant food, could regulate breeding in this species. This possibility has now been investigated in adult animals caught in the wild and then kept in controlled laboratory conditions.

Hopping mice (Notomys alexis) were obtained near Curtin Springs, Northern Territory, between 14 and 17 May 1975. Seven females were killed in the field, and the rest were returned within 3 days to the laboratory in Adelaide where they were randomly allocated to one of the following groups. Group 1 was the control group; the females were kept singly in cages $(26 \times 13 \times 11 \mathrm{~cm})$, fed a mixture of dry seed, and had free access to water. Groups 2, 3 and 4 were kept similarly, except that Group 2 animals were given supplementary apple and Oxoid cubes once per week, no water was provided for those in Group 3, and Group 4 animals were housed 4 per cage. All animals were kept in light cupboards ( $16 \mathrm{hr}$ light/24 hr) in an isolated room with no other animals present; the temperature was $22 \pm 6^{\circ} \mathrm{C}$ and relative humidity ranged from $45-60 \%$. Animals in Group 5 were housed and fed like those in Group 1, but the cages were placed in the general animal room.

All animals were inspected daily for vaginal perforation and vaginal smears were taken if this had occurred. After 82 days of treatment, animals in Groups 1 and 3 were killed, reproductive organs were weighed and $7 \mu \mathrm{m}$ serial sections of the ovaries were prepared for assessment of ovarian activity. The animals in the other groups were used for other experiments.

All females obtained in the wild had imperforate vaginae and the 7 representative females killed in the field had mean ( \pm S.E.M.) body weights of $38.3 \pm 3.0 \mathrm{~g}$, ovarian weights of $1.5 \pm 0.1 \mathrm{mg}$ and uterine weights of $12.5 \pm 2.5 \mathrm{mg}$. There were no corpora lutea (CL) or vesicular follicles in any of the ovaries. The animals had considerable stores of body fat, a condition not usually found in waterdeprived animals, and the inactive ovarian condition, in spite of normal adult body weights, could therefore have been due to the very high density of animals in the place where these were caught (see Christian, 1971); 110 hopping mice were obtained in the 200 traps set during the 4-day period.

Table 1 shows that no significant differences occurred in the time at which females emerged from their inhibited state in Groups 1,2 and 5. However, the females in Group 4 experienced delayed vaginal perforation and occurrence of first oestrus and only 7 of the 16 females subsequently had regular cycles. All water-deprived females became perforate (Group 3) but perforation was delayed and only $2 / 8$ animals subsequently showed regular vaginal smear changes. Regardless of treatment, when regular oestrous cycles occurred they were usually 7-10 days in length, but when females became perforate and did not show regular cycles, they had prolonged periods of dioestrus with thin leucocytic smears.

At the end of the experiment, water deprivation for 82 days had not resulted in any deaths and the overall mean body weight was only slightly lower than that at the start of the experiment, ovarian weights were marginally less than those of control animals whilst the difference between uterine weights was nearly statistically significant $(0.05<P<0.1)$. Inspection of the results for individual animals, however, showed that 3 out of the 8 water-deprived females had body, ovarian and uterine weights similar to those of the controls and healthy-looking CL were subsequently found in the ovaries of 2 of the 3 females at autopsy, whereas the other 5 animals had much lighter body, ovarian 
Table 1. Mean \pm S.E.M. time (days) of vaginal perforation and first oestrus and length of the oestrous cycle of wild hopping mice placed in vatious environmental conditions in the laboratory

\begin{tabular}{|c|c|c|c|c|c|}
\hline \multirow[b]{2}{*}{ Group } & \multirow[b]{2}{*}{$\begin{array}{l}\text { No. of } \\
\text { animals }\end{array}$} & \multicolumn{2}{|c|}{ Time from beginning of treatment to: } & \multirow{2}{*}{$\begin{array}{l}\text { No. of } \\
\text { animals } \\
\text { with } \\
\text { regular } \\
\text { oestrous } \\
\text { cycles }\end{array}$} & \multirow[b]{2}{*}{ Cycle length $\ddagger$} \\
\hline & & $\begin{array}{c}\text { Vaginal } \\
\text { perforation }\end{array}$ & $\begin{array}{c}\text { First oestrous } \\
\text { smear }\end{array}$ & & \\
\hline 1 Control & 6 & $27 \pm 5$ & $32 \pm 6$ & 5 & $8 \cdot 1 \pm 0.9(29)$ \\
\hline 2 Supplementary diet & 6 & $39 \pm 8$ & $45 \pm 9$ & 4 & $8.7 \pm 0.3(18)$ \\
\hline 3 Water-deprived & 8 & $55 \pm 5^{*}$ & $35,55 \dagger$ & 2 & $8.7+0.4(8)$ \\
\hline 4 Grouped & 16 & $43 \pm 4 * *$ & $57 \pm 9^{* *}$ & 7 & $9.2 \pm 0.9(42)$ \\
\hline 5 Animal room & 5 & $37 \pm 9$ & $41 \pm 9$ & 5 & $7.5 \pm 0.2(18)$ \\
\hline
\end{tabular}

Significantly different from control: ${ }^{*} P<0.002 ; * * P<0.05$ (unpaired $t$ tests).

$\dagger 6$ and 9 days after vaginal perforation; only these females cycled regularly.

$¥$ The number of cycles analysed for each group is given in parentheses. When the dioestrous period was 14 or more days in length the cycle was considered abnormal and excluded from the analysis. This usually occurred only in animals in Groups 3 and 4.

Table 2. Effect of water deprivation for 82 days on body and reproductive organ weights and ovarian histology of wild-caught female hopping mice (means \pm S.E.M.)

\begin{tabular}{|c|c|c|c|c|c|c|c|c|}
\hline \multirow[b]{2}{*}{ Group } & \multirow{2}{*}{$\begin{array}{l}\text { No. of } \\
\text { anim- } \\
\text { als }\end{array}$} & \multicolumn{2}{|c|}{ Body wt (g) } & \multirow{2}{*}{$\begin{array}{l}\text { Ovarian } \\
\text { wt (mg) }\end{array}$} & \multirow{2}{*}{$\begin{array}{l}\text { Uterine } \\
\text { wt (mg) }\end{array}$} & \multirow{2}{*}{$\begin{array}{l}\text { No. of } \\
\text { females } \\
\text { with CL }\end{array}$} & \multirow{2}{*}{$\begin{array}{l}\text { No. of } \\
\text { vesicular } \\
\text { follicles }\end{array}$} & \multirow{2}{*}{$\begin{array}{l}\text { Maximum } \\
\text { size of } \\
\text { vesicular } \\
\text { follicles } \\
(\mu \mathrm{m})\end{array}$} \\
\hline & & Initial & Final & & & & & \\
\hline & 6 & & $39 \cdot 2$ & 1 & $80 \cdot 6 \pm$ & $5 /$ & & \\
\hline & 8 & $32 \cdot 2 \pm 2 \cdot 9$ & $31.8 \pm 2.9$ & $5.9 \pm 1 \cdot 2$ & $39 \cdot 6 \pm 11 \cdot 8$ & $2 / 8^{*}$ & $4.9 \pm 1.3$ & $511 \pm 35$ \\
\hline
\end{tabular}

* Significantly different from control, $P<0.05\left(\chi^{2}\right.$ test $)$.

and uterine weights and no CL were present. Although the numbers of vesicular follicles did not differ significantly, the sizes of Graafian follicles in the 3 water-deprived females with normal ovarian weights were similar to those of controls but were smaller in the other 5 animals.

The above results show that in inhibited wild-caught adult animals, neither a supplementary diet nor proximity of reproductively active animals had any significant effect on time of vaginal perforation, time of first oestrus or length of the oestrous cycle, but caging in groups of 4 delayed vaginal perforation and oestrus and inhibited normal cyclicity in some individuals. Water deprivation also delayed vaginal perforation and prevented normal cyclicity in some, but not all, wild females. Previously it had been found that, in laboratory-bred animals, water deprivation usually prolonged the dioestrous period and resulted in decreased body, ovarian and uterine weights. However, in the wild-caught water-deprived females with cyclical changes in vaginal smears, low body or reproductive organ weights were not apparent at the end of the experiment.

Although the situation in the natural environment is complex, the present results suggest that maximum breeding activity in female hopping mice is prevented when water availability in green plants is scarce or population density is high. A small percentage of animals does, however, appear to be capable of cyclic ovarian activity in times of water deprivation. Baverstock \& Watts (1975) have shown that occasional hopping mice can maintain lactation under similar conditions, although water-deprived female gerbils failed to produce any young even when ovarian and uterine weights did not differ from those of controls (Yahr \& Kessler, 1975). A number of studies of kangaroo rats have shown a correlation of breeding activity and availability and/or ingestion of green plants (see Beatley, 1969; Bradley \& Maurer, 1971; Reichman \& van der Graaft, 1975), and maximum 
breeding activity of jerboas coincides with the rainy season in the Sudan (Ghobrial \& Hodieb, 1973). In several species of desert rodent, therefore, it appears that breeding is at least greatly limited if no water, or green vegetation, is available, but in hopping mice considerable variability occurs between individuals in their response to water deprivation.

Taking these results together with those previously reported (Breed, 1975), it appears that the effect of water deprivation on ovarian activity may be related more to a generalized effect on the condition of the animal than to a specific inhibitory effect on ovarian function. If marked decrease in body weight occurs, reduced ovarian activity follows, whereas if no such effect on body weight takes place the ovaries continue to function normally. The inhibition of activity induced by high population density, as in the wild animals at the time of capture and in some of the animals caged in groups of 4 , is, however, presumably effected through the neuroendocrine system.

\section{References}

Baverstock, P.R. \& Watrs, C.H.S. (1975) Water balance of small laboratory rodents 1 . Ad libitum water intake and effects of water restriction on growth of young. Comp. Biochem. Physiol. 50A, 819-825.

Beatley, J. (1969) Dependence of desert rodents on winter annuals and precipitation. Ecology 50, 721-724.

BRADley, W.G. \& MAURER, R.A. (1971) Reproduction and food habits of Merriam's kangaroo rat, Dipodomys merriami. J. Mammal. 52, 497-507.

BreEd, W.G. (1975) Environmental factors and reproduction in the female hopping mouse, Notomys alexis. J. Reprod. Fert. 45, 273-281.
Christian, J.J. (1971) Population density and reproductive efficiency. Biol. Reprod. 4, 248-294.

Ghobrial, L.I. \& Hodieb, A.S.K. (1973) Climate and seasonal variation in the breeding of the desert jerboa, Jaculus jaculus, in the Sudan. J. Reprod. Fert., Suppl. 19, 221-233.

REICHMAN, O.J. \& VAN DER GRAAFT, K.M. (1975) Association between ingestion of green vegetation and desert rodent reproduction. J. Mammal. 56, 505-506.

YAHK, P. \& KESSLER, S. (1975) Suppression of reproduction in water-deprived Mongolian gerbils (Meriones unguiculatus). Biol. Reprod. 12, 249-254.

Received 27 January 1976 